\title{
RETRATO DA ENCICLOPÉDIA HEGELIANA QUANDO VISTA DO BRASIL
}

\author{
Ronie Alexsandro Teles da Silveira ${ }^{1}$ \\ Universidade Federal do Sul da Bahia (UFSB) \\ (D) https://orcid.org/0000-0003-3046-655X
}

\section{RESUMO:}

Em 2016 comemoram-se os 200 anos de publicação da "Enciclopédia das Ciências Filosóficas" de Hegel. Esta parece ser uma ocasião especial para se poder avaliar a pertinência da "Enciclopédia" para o Brasil. Essa avaliação, aqui elaborada, conduz à percepção de que se a filosofia é pensar o presente, então a "Enciclopédia" não pode ser compreendida como contendo problemas e soluções para o Brasil, mas apenas para a velha Europa. Portanto, nessa ocasião se torna especialmente perceptível a necessidade de se abandonarem as velhas categorias da Europa como instrumentos para se pensar o Brasil.

PALAVRAS-CHAVE: Hegel; Enciclopédia; Brasil; Europa.

\section{PORTRAIT OF THE HEGELIAN ENCYCLOPEDIA FROM THE BRAZIL'S POINT OF VIEW}

\begin{abstract}
:
In 2016 to celebrate the 200th anniversary of the publication of Hegel's "Encyclopedia of Philosophical Sciences". This seems to be a special occasion to be able to assess the relevance of the "Encyclopedia" for Brazil. This assessment, prepared here, leads to the realization that if philosophy is to think the actual, then the " Encyclopedia " cannot be understood as containing problems and solutions to Brazil, but only for the old Europe. So in this time is especially noticeable the need to abandon the old categories of Europe as tools to think about Brazil.
\end{abstract}

KEY WORDS: Hegel; Encyclopedia; Brazil; Europe.

\footnotetext{
${ }^{1}$ Mestre em filosofia, doutor em psicologia e professor da Universidade Federal do Sul da Bahia (UFSB), Bahia - Brasil.
} 


\section{Introdução}

Em 2016 comemoram-se os 200 anos de publicação da "Enciclopédia das Ciências Filosóficas" de Hegel (1986; 1988; 2004). Em 1816, na ocasião de sua publicação, o Brasil sequer era um país independente e vivia mergulhado em uma situação colonial típica, sem nenhum vestígio de autonomia política. Os portos haviam sido abertos para algum comércio em 1808, com a chegada da família de Bragança ao país, fugidos da invasão napoleônica. Embora a presença da família real no país e sua elevação à condição de reino unido possam ter fornecido uma nova perspectiva ao Brasil, ela não alterou profundamente nosso ritmo de vida.

Talvez a maior evidência disso seja o fato de que a Independência tenha significado mais uma tentativa de manter os Bragança no poder, tanto lá quanto cá, do que propriamente uma tentativa de redefinição da vida nacional. Com efeito, a declaração de rompimento de nossos laços com Portugal, realizada por um português, foi mais uma reação à possibilidade de retornarmos à condição anterior de colônia, quando confrontada com a situação recém-adquirida de reino unido do que um amadurecimento de nossa consciência nacional (FAORO, 1973). Em último caso, a independência foi promovida mais por Napoleão, quando invadiu Portugal e criou a figura política do reino unido, do que pelos próprios brasileiros. Foi essa situação que se tornou uma espécie de limite a partir do qual não seria mais possível retornar ao passado de dependência com relação a Portugal.

A situação colonial típica, a que me referi acima, inclui certamente a ausência de autonomia, não somente política, mas também filosófica. Além disso, ela envolve outros aspectos que constituem elementos de um verdadeiro complexo colonial. A ruptura do modo de vida provocada pela chegada do colonizador abre uma nova condição para a qual o colonizado não está preparado. Fanon (1952, p. 79) descreveu essa experiência como a da irrupção de uma "ferida absoluta" no modo de vida indígena. Isso porque ela fende o mundo em dois momentos: antes e depois da chegada do colonizador. Depois dele, a vida não pode mais recuar para a situação preexistente e só pode marchar para frente, para dentro do universo do colonizador. Isso quer dizer que a vida do colonizado, queira ele ou não, deverá ser uma vida balizada, em alguma medida, pelos valores do colonizador.

Glauber Rocha (1970) ilustrou, por mais de uma vez ao longo de sua obra cinematográfica, o processo de imitação a que pareciam condenadas as elites nacionais dos países colonizados. A figura mais típica dessa tentativa farsesca de se libertar da situação de colonizado é seguramente a do presidente africano vestido de nobre francês, com direito à peruca grisalha $\mathrm{e}$ fraque, personagem em "Der Leone have sept Cabezas", filmado no Congo. Se há algo digno de nota nessa caricatura é o fato de que nele se torna 
expresso justamente o fato de que, a partir da colonização, a vida do colonizado terá que acertar-se com os valores culturais do colonizador. Mesmo que, nesse caso, isso ocorra sob a forma de caricatura, trata-se de uma tentativa de assimilar o modo de vida do colonizador.

Qualquer forma de resistência também joga água no moinho do colonizador, contra o qual se torna necessário lutar, de armas em punho ou por meios culturais. Seja qual for a modalidade de resistência, ela é uma luta contra o colonizador e, nesse caso, ainda é ele quem fornece a baliza e demarca o terreno onde se tem de lutar para sobreviver.

Nossa ferida absoluta foi produzida em 1500 e tudo indica que ainda não estávamos em condições de expressar algum grau de autonomia política e filosófica 300 anos depois, quando Hegel publicou a "Enciclopédia". Naquele momento nenhuma apreciação brasileira do projeto enciclopédico podia ser esperada, quando ainda mal começávamos a preparar os primeiros movimentos de imitação de um Estado nacional e, quem sabe, as primeiras tentativas de um correlato farsesco filosófico.

Que se trata da imitação de um Estado nacional e não da criação de um, isso fica evidente em função de um dos aspectos do peculiar complexo colonial criado aqui. Com efeito, se o Estado é uma figura que emerge no ambiente político europeu para eliminar as contradições da sociedade civil e pacificar a sociedade, como defendeu Hegel (1997), essa situação jamais se apresentou no território brasileiro. Aqui as relações políticas foram marcadas pelo regime das convocações. Trata-se de um dispositivo político, estabelecido pela Carta Régia de 1776, que definia as normas para reunir a população colonial através da força e formar vilas. Esse poder era delegado a um mandatário, o capitão-mor regente. Esse passava a usufruir do comando político, da aplicação da lei e da manutenção da ordem. Ou seja, era um pequeno ditador a quem se outorgava o direito de constituir uma sociedade civil (COIMBRA, 1971) por meio do cativeiro e da unificação violenta de uma população que vivia espalhada e sem nenhuma forma de contato comunitário.

Isso tudo em um território que, para tornar as coisas ainda mais distintas do universo europeu, se julgava "elástico" (OLIVEIRA LIMA, 2000, p. 67) em função de sua contínua expansão para o interior. Assim, se não havia uma sociedade civil em situação de conflito interno, não existia igualmente um território geográfico específico a ser consolidado sob a unidade política do Estado. Portanto, não havia sobre o quê fundar um mundo político orgânico em função da ausência de sociedade e de território. No Brasil colonial a situação era verdadeiramente a de um Estado carente à procura de uma sociedade para chamar de sua.

A peculiaridade histórica da situação permite que tenhamos tido (ou tenhamos ainda hoje) somente uma imitação de Estado nacional já que seus requisitos básicos, incluindo aquela sociedade civil internamente contraditória, inexistiam na época colonial. Ou seja, por aqui se fez um 
Estado sem suas respectivas condições de possibilidade - um simulacro, uma instituição sem substância social.

Em função dessa situação peculiar, é provável que uma avaliação genuinamente brasileira da "Enciclopédia" por ocasião de sua publicação, não tivesse mesmo sido de nenhuma utilidade. Não há sequer como imaginar como se poderia estabelecer uma comunicação entre extremos tão diferentes do complexo colonial. Mais provável seria imaginar que os velhos europeus pudessem estabelecer um diálogo mais proveitoso com marcianos recém-chegados ao planeta. Uma apreciação filosófica da "Enciclopédia" hegeliana, no momento de sua publicação, deveria se apresentar - se fosse possível - com uma forma de simulacro filosófico, no mesmo sentido do nosso Estado nacional da época da Independência.

Isso obviamente não significa que essa comunicação entre a Metrópole e a Colônia seja definitivamente impossível, mas que ela requer um momento apropriado para se estabelecer. Principalmente porque o tipo de comunicação que estou propondo nesse texto supõe a possibilidade de uma reversão dos papéis tradicionais estabelecidos entre o colonizador e o colonizado. Refiro-me à possibilidade de uma avaliação, feita do ponto de vista brasileiro, sobre a "Enciclopédia" hegeliana e seu entorno moderno. Não se trata de uma descrição da recepção dessa obra por aqui ou de sua eventual adaptação aos trópicos brasileiros e sim de submetê-la ao crivo do nosso ponto de vista.

É verdade que o significado de nosso ponto de vista é altamente polêmico, principalmente nesse contexto. Como não posso me estender demasiadamente aqui, remeto o leitor ao livro "Apresentação do Brasil" (SILVEIRA, 2015) em que ele está descrito com certa precisão. Advirto, entretanto, que dificilmente os intelectuais brasileiros se reconhecerão no que chamo de nosso ponto de vista. Porém, isso está ligado ao fato de que eles são ou representantes ou interlocutores da velha Europa e, por isso mesmo, não adotam o nosso ponto de vista. Nesse caso, a atividade intelectual é realizada no Brasil, porém ela ocorre inteiramente voltada para a velha Europa e a tem como referência principal. Uma das consequências dessa maneira de pensar é que, ao tratar do Brasil, ela recai invariavelmente no discurso da carência: uma enumeração de tudo o que nos falta para nos tornarmos europeus. Portanto, ela opera inteiramente adaptada ao complexo colonial e reafirma-o constantemente.

Pretendo tentar aqui um gesto na direção dessa avaliação, agora em 2016, supondo que o nosso ponto de vista está estabelecido em outra parte por uma questão de economia expositiva. Essa avaliação incidirá sobre a "Enciclopédia" hegeliana, esse texto tão típico da modernidade filosófica produzida pela velha Europa. Certamente não há como estabelecer condições teóricas prévias que garantam que tal avaliação seja efetivamente possível e viável: gestos de autonomia, como em geral qualquer gesto, devem ser demonstrados por meio de sua realização e não através de alguma 
modalidade de fundamentação. Mesmo se tratando de um gesto teórico, o que pretendo aqui ainda é um gesto e só poderá encontrar sua devida justificativa no mundo prático dos gestos.

Ressalto, entretanto, que o gesto de avaliar a "Enciclopédia" a partir do Brasil não pretende ser o equivalente a um grito do Ipiranga filosófico já que, como vimos, faltou substância social brasileira ao grito do Ipiranga político. Dessa maneira, esse gesto de avaliação ainda faz parte do mesmo complexo colonial estabelecido em 1500, mas não o reafirma.

Embora por meio dele se busque inverter a relação tradicional forjada pela velha Europa - entre quem fornece o critério e quem se submete a ele - ainda assim se trata de uma modalidade de avaliação: aquele mecanismo de crítica que cria a miragem da distância para, só então, produzir a sensação paradoxal de uma proximidade impessoal com relação ao seu objeto. $\mathrm{O}$ paradoxo do dispositivo crítico consiste em que a visão correta, que nos permite ver as coisas como elas são, nos é fornecida quando nos afastamos delas. Como se trata aqui de uma avaliação, ainda me movimento dentro desse dispositivo e, portanto, navego nas águas do complexo colonial.

Como não podemos escapar desse complexo por meio da crítica, já que esse é o seu próprio método, a única função desse texto é tornar explícito que já sabemos imitar o colonizador com um grau de perfeição do qual talvez nem ele seja capaz. Isto é, esse texto tenta mostrar que o fraque e a peruca grisalha nos caem tão bem que qualquer um, assistindo ao espetáculo, pode nos confundir com um velho europeu. $\mathrm{O}$ gesto de elevar-se no ar com a destreza do colonizador significa um gesto limítrofe, porém ainda dentro do dispositivo colonial. Depois dele, certamente não fará mais sentido seguir adiante na corrente da vida da velha Europa.

O gesto imitativo de inversão da crítica é, no caso extremo, um gesto carnavalesco que revela que se trata, afinal, apenas de uma imitação e não de um gesto autêntico. O colonizado sabe, em 2016, que jogar o jogo do colonizador é uma farsa que ele deve realizar com certa seriedade fingida para demonstrar-se capaz de ser considerado como um outro autêntico, e não mais como a sombra menor de um ser humano. Para o colonizador isso deve parecer o sucesso da colonização e a aceitação dos valores da velha Europa no coração da colônia, já que seu interlocutor parece ter se tornado um velho europeu. Para nós, brasileiros, se trata de demonstrar que esses valores foram anulados e de que o complexo colonial teve sua essência suprimida.

Em último caso, esse gesto crítico do colonizado é ambíguo: para si mesmo ele consiste em uma imitação primorosa e libertadora, justamente porque é uma farsa e não outra vida não europeia com o mesmo conteúdo dela. Para o colonizador ele significa a vitória dos seus valores, pois a imitação lhe parece exímia e digna do original. Tudo consiste, portanto, nessa habilidade de passar a perna no colonizador e realizar uma crítica que 
pareça séria aos olhos da velha Europa e não passe de uma farsa libertadora para nós. Se levarmos a sério a crítica, estaremos concedendo a vitória ao colonizador, porque isso equivale a jogar o jogo dele, segundo as regras dele e arbitrado pelo seu espírito. Como farsa, a crítica é dele, o jogo também, porém as regras são manipuladas pelo nosso espírito leviano. Por isso, a crítica do colonizado só pode se dar sob a forma de uma burla, de uma enganação. Esse método é essencial porque só ele pode quebrar a lógica do complexo colonial.

Para os intelectuais brasileiros, que avaliam criticamente as coisas do ponto de vista da velha Europa, essa crítica da "Enciclopédia" parecerá digna de respeito. Para os brasileiros, ela será apenas mais um lance em um jogo adaptado e em que tentamos nos divertir.

\section{A força unificadora do conceito}

O motor subjacente às pretensões totalizadoras da "Enciclopédia" hegeliana é a força unificadora do conceito (HEGEL, 1986; 1988; 2004). Mas esse motor não exerce uma força acachapante que esmaga os conteúdos por onde quer que passe, uniformizando-os como se fosse um rolocompressor. Trata-se, ao contrário, de colocar em movimento uma energia sutil e fluída que agrega esses conteúdos em sua própria corrente, tomando novo e vigoroso impulso justamente por meio dessa agregação. Esse rio caudaloso, o processo dialético de fagocitose semântica, é o que chamamos de suprassunção em hegelianês - o dialeto hegeliano.

Em tal processo podemos distinguir duas situações, separáveis somente como estratégia para tornar o procedimento enciclopédico mais claro. Na primeira situação temos o conteúdo específico em sua própria condição positiva, isto é, como um dado. Ele se apresenta, na "Enciclopédia", seja como conteúdo da história, seja como determinação da lógica, seja como filosofia, seja como religião. O que conta aqui é que ele se apresenta com um conteúdo positivo, dotado de um sentido que se encontra agregado à sua própria condição de dado.

$\mathrm{Na}$ segunda situação, opera-se a fagocitose dialética propriamente dita. Isto é, o dado é inserido em uma corrente que o reinterpreta, dotando-o de um sentido novo e distinto do primeiro. Essa nova significação diz respeito à função específica desse elemento para a totalidade do desenvolvimento dialético ou revela seu verdadeiro sentido conceitual. Essa distinção em dois momentos equivale àquela elaborada por Labarrière (1979) ao distinguir entre história e história conceitual, porém aqui generalizada para a estrutura dialética da "Enciclopédia".

Note, para bem da verdade, que o próprio Hegel repudiaria esse meu recurso retórico de apresentar a estrutura formal da "Enciclopédia" na medida em que ele procede a uma separação hegelianamente ilegítima entre forma e conteúdo. Observo, entretanto, que se trata de um mero recurso 
retórico - do qual o próprio Hegel lança mão eventualmente apesar de declará-lo dialeticamente inadequado.

Há em toda dinâmica enciclopédica um impulso original para a obtenção da concreção, para a consolidação de uma apropriação do conceito por si mesmo, através de seus vários momentos. É o deslocamento dessa corrente, tensionada originalmente pela falta de adesão a si mesmo, pela carência de imanência plena e de completude, que deságua como uma torrente englobando conceitualmente o material que encontra pelo caminho.

A força motriz do movimento é a inadequação entre o que o conceito é e o que ele sabe de si. Trata-se, portanto, da necessidade de saber-se plenamente, de entrar na posse total do que lhe é próprio, de obter a imanência através da experiência da transcendência e tornar-se "objeto para si mesmo tal como ele é" (HEGEL, 1992, p. 41). O que está em questão na "Enciclopédia", portanto, é a realização plena do saber absoluto - postulado desde a "Fenomenologia do Espírito".

Com isso, podemos perceber o que há de decididamente moderno na "Enciclopédia" hegeliana: sua compulsão pela ordem. Embora nesse caso não se trate de impor uma subordinação simples do particular ao universal, ainda assim estamos no interior de um dispositivo cultural que busca unificar o múltiplo da vida, o conjunto variado da positividade e a riqueza do que é dado. Justamente porque não se trata de mera subsunção, é que o elemento particular deve ser suprassumido, como já vimos. Porém, mesmo no contexto desse processo sutil de fagocitose semântica, notamos o mesmo impulso moderno pela unidade, pelo ordenamento da multiplicidade, pelo regramento uniforme de uma paisagem variada.

Essa compulsão manifesta-se por uma diversidade de fenômenos da vida moderna, de tal forma que não há como indicar um deles como se constituindo em causa exclusiva de todos os demais. Assim, do ponto de vista político, a compulsão se manifesta como um Estado centralizado exercendo domínio sobre um vasto território geográfico. Do ponto de vista econômico, ela aparece como a monetarização da economia sob a figura de uma forma geral única da riqueza - a moeda - que regula o sistema de trocas. Do ponto de vista moral, ela indica a necessidade de ordenamento do sujeito que decide subordinar as várias facetas da vida a um conjunto de regras superiores.

Em todos esses dispositivos de homogeneização as exceções não são bem-vindas. Daí me parecer oportuno falarmos de uma verdadeira compulsão pela unidade. Um Estado que não exerce sobre seu território e sobre sua população um controle efetivo é um Estado débil. Nesse caso, temos um aparato de poder incapaz de domínio central exclusivo, da manutenção da ordem, da execução uniforme das leis etc. - algo que conhecemos muito bem no Brasil, pelo menos quando descrito por aquele discurso da carência, típico do complexo colonial. Essa fragilidade implica em que alguma parte da população e/ou alguma parte do território escapa da 
unidade do poder e torna-se poder paralelo. Isto é, ela fraciona e multiplica o poder.

Da mesma forma, um sistema econômico que não dispõe de uma moeda única não é um sistema econômico, porque não é capaz de reunir a multiplicidade existente das mercadorias sob uma referência de valor comum e regrar uniformemente o fluxo de trocas. Pela mesma lógica, um sujeito incapaz de ordenar-se moralmente é entendido, da perspectiva moderna, como um sujeito incompleto ou sem energia moral suficiente para exercer controle sobre sua própria vida. Essa autorregência que lhe forneceria uma feição uniforme e constante - ou um caráter. Sem ela, o homem é dominado pelas suas tendências e oscila ao sabor delas.

O panorama geral presente em todas essas situações e em outras tipicamente modernas, demanda uma ação unificadora, de fazer valer sobre uma diversidade de elementos uma regra, referência ou processo que permita o fluxo do poder, o deslocamento da riqueza, a homogeneidade da pessoa, a constância, o regramento e a ordem. É justamente a homogeneização do meio que torna todas essas realidades possíveis. Ela se constitui como um patamar universal de tradutibilidade e uniformização para os elementos variados da vida, uma plataforma em que a comunicação e a transação se tornam possíveis.

Em todas as circunstancias de fracasso da modernização, notamos que a unidade da multiplicidade, mesmo na sua versão dialética suprassumida, não se cumpre ou não chega a se mostrar efetiva, no que diz respeito a produzir um mundo organizado segundo princípios gerais. $\mathrm{O}$ fracasso da modernidade chama-se fragmentação, interrupção, diversidade substantiva ou transcendência perseverante.

Não é ocasional que Hegel tenha identificado na radical separação judaica entre matéria e espírito um dos antípodas principais do seu pensamento dialético. Afinal, essa divisão persistente das coisas revela-se uma indisposição para que um elemento se mova em direção ao outro, que o espírito apareça como a matéria e que essa, por sua vez, seja conformada por aquele. O problema aqui é que cada um desses elementos "existe imutavelmente nessa única modalidade" (1985, p. 504) inicial, impedindo que o impulso dialético de unificação das partes tome vulto. Ele faz estancar os dados iniciais como fragmentos, persevera teimosamente em si mesmo e vive uma vida cindida entre opostos imutáveis.

Para qualquer dispositivo moderno, assim como para as intenções enciclopédicas hegelianas, a impossibilidade da corrente dialética de desaguar sobre a multiplicidade é um obstáculo crucial que precisa ser superado para que se produza a unidade. Daí as críticas de Hegel ao entendimento: uma maneira de pensar que se aferra à "determinidade fixa" e que se julga no direito de "subsistir e ser por si mesma" (1986, p. 188). Essa perseveração na própria substancialidade é que impede a manifestação da 
autêntica natureza do conceito, a realização do seu devir interiorizante. E é do devir hegeliano que brota a verdade da unidade superior.

A "Enciclopédia" hegeliana ocupa um lugar especial no panorama geral da modernidade filosófica justamente pelo fato de que a unidade que ela busca estabelecer não é o resultado da mera subordinação da multiplicidade. A suprassunção é o mecanismo que permite que o elemento fragmentário seja incorporado ao movimento de concreção do conceito sem supostamente perder sua especificidade.

Embora essa preservação do ser do múltiplo possa ser objeto de alguma polêmica, em função das alterações de sentido que a suprassunção promove, não me parece que isso seja relevante aqui. Basta verificarmos que o que o conceito busca é obter para si uma unidade entre o ser e o saber, algo de que ele está desprovido no início. Para isso, ele precisa conquistar uma paisagem diversa que se estende diante dele, trespassá-la por meio de um movimento de fagocitose semântica, restabelecendo sua verdade como momento de sua própria vida interior. A transposição da transcendência em imanência exige a conformação do múltiplo exterior no sentido da adoção de um significado para o conceito, isto é, a instituição de um novo sentido interior. E é essa compulsão pela unidade que é típica da "Enciclopédia".

\section{A crucificação}

Justamente por se constituir como parte dos dispositivos modernos da velha Europa, é que a "Enciclopédia" hegeliana é uma modalidade filosófica de Cristianismo ou, se preferirmos, uma forma de Cristianismo para filósofos. Vimos que o motor do movimento dialético que conduz o projeto enciclopédico é a inadequação do espírito com relação a si mesmo, seu desconforto original e sua impossibilidade de repouso na condição em que se encontra. Ou seja, o que se apresenta desde o início e que move a atividade posterior de recapitulação conceitual é uma insatisfação do espírito com sua condição ontológica, um desgosto pelo fato de que ele não é como deveria ser. O espírito hegeliano é um ser insatisfeito consigo mesmo, que não vê em si mesmo senão algo que deve ser sacrificado para que, a partir daí, ele possa renascer melhor ou, em hegelianês, plenamente espiritualizado, em si e para si.

É essa insatisfação original, essa sensação de incompletude, que conduz à crucificação de toda transcendência, para que ela possa ser posteriormente restituída sob a forma da imanência. Há, portanto, a expectativa da emersão de um significado verdadeiro que eclodirá no processo de interiorização e que substituirá o sentido dado, isto é, falso. Durante o transcurso dialético esse significado ainda não é transparente para o espírito, ele ainda não se mostra plenamente. Só a caudal dialética será capaz de revelá-lo em sua verdade definitiva. Enquanto nos mantemos presos em operações de pensamento não dialéticas, vivemos sem conhecer a 
verdade, exilados do espírito reconciliado. Desse último ponto de vista não há como saber que sentido será constituído e surgirá do processo, porque esse ainda não foi concluído.

Trata-se, ao fim e ao cabo, de uma modalidade filosófica da crença na providência divina: de que Deus escreve certo por linhas tortas. Nós, de nossa perspectiva humana, não vemos o verdadeiro sentido dos acontecimentos, em função de nossa natural limitação. Mais tarde, quando julgarmos os eventos sob a ótica correta, o ponto de vista do próprio Deus, tudo se revelará e fará sentido: algumas coisas significarão algo para o processo dialético de recuperação da transcendência e muitas serão totalmente irrelevantes para a vida absoluta. A separação do que é efetivamente significativo do que não é só se dará quando rasgarmos o véu que envolve o sentido conceitual oculto no que é dado, quando abandonarmos o estreito ponto de vista do ser humano empírico.

Até lá, até o advento fulgurante do clarão racional que afastará as trevas semânticas de nossos olhos, devemos nos manter confiantes de que tudo se revelará um bem para o espírito. Não apenas isso, mas devemos atentar também para o fato de que o espírito encontra-se originalmente exilado de si mesmo. Isso quer dizer que o sofrimento circunstancial, eventualmente contido em qualquer presente histórico, pode ser insignificante para a introjeção definitiva do espírito em si mesmo. De fato, o sofrimento dos seres humanos pode nada dizer para o reino da interioridade dialética e, caso ele diga algo, estará mesmo assim justificado em função de seu eventual sentido superior, a ser revelado na ocasião propícia de reconhecimento. Nesse sentido, a metáfora sangrenta de uma crucificação necessária para a eclosão da espiritualidade do espírito fala por si mesma.

A astúcia da razão que se move por dentro do conceito não recompõe o sentido da vida humana senão como um sentido crucificado, um sentido suprassumido ou reconfigurado pela fagocitose semântica do espírito. Em último caso, aquilo que se passa da perspectiva do ser humano pode não ser significativo e, se o for, certamente não o será da mesma perspectiva com a qual ele vive sua existência particular. A vida humana empírica deve ser superada para que dela possa emergir a perspectiva espiritual autêntica. Como tal, como é dada a nós, a vida humana ainda não é autêntica. Daí a necessidade da crucificação dialética do ser humano.

De certa forma, a "Enciclopédia" também tenta realizar uma versão absoluta daquilo que a ética kantiana defendeu como uma meta individual: a obtenção da autonomia (KANT, 1973). O problema filosófico contido na busca por autonomia, e que me parece relevante nesse contexto, é a reação desencadeada pelo reconhecimento do problema inicial que ela tenta dissipar: a heteronomia. Na condição heteronômica o ser humano se vê dominado por forças estranhas, por um mundo ameaçador que o cerca e o controla. 
A eloquente reação diante dessa situação é a tentativa de libertar-se dessas forças estranhas por meio de um controle sobre si mesmo. A obtenção da autonomia é justamente o sucesso na substituição do domínio dos outros pelo autodomínio, da tomada de poder para nossas próprias mãos, do estranho pelo conhecido, do exterior pelo interior. Com esse projeto de autonomia assumimos a necessidade de um exercício do poder permanente, já que se trata sempre, na heteronomia, de um poder ameaçador dos outros. A única forma de se obter a autonomia é por meio da substituição das forças estranhas pela nossa própria força. A autonomia é, portanto, o sucesso no uso da força.

Vemos aqui claramente formulado o projeto de busca da unidade por meio da interiorização, pela conquista e domínio de um mundo originalmente estranho e ameaçador, pelo controle dos elementos que ameaçam o homem. O que a autonomia e a "Enciclopédia" tentaram eliminar foi a sensação de temor que aflige o ser humano quando esse se percebe atirado em um mundo dominado por forças estranhas. Forças que constituem um mundo heteronômico que, dessa perspectiva, não pode ser nossa casa definitiva. Essa sensação de temor diante de um mundo estranho é o chão comum de onde brotam o Cristianismo e a "Enciclopédia".

Não é necessária muita sagacidade para reconhecer na procura por autonomia, seja no plano ético kantiano, seja no ambiente absoluto hegeliano, uma reação da velha Europa cristã à expulsão do Paraíso. O que se procura é a eliminação da falha original, do pecado com o qual os europeus cristãos se julgam marcados a ferro e fogo desde o pecado original. É a imanência e a completude que devem ser refeitas, e é a totalidade do mundo que precisa ser reconstituída por dentro, de tal forma que os fragmentos se reúnam de maneira satisfatória.

O mito da identificação plena com a alteridade, da resolução de toda problemática da transcendência, do encontro com um outro que não sou eu, da adesão ao que é estranho e se mostra - por isso mesmo - ameaçador, isso é o que está em questão no fundo cristão da "Enciclopédia". O que ela encena é a recondução dos exilados para o seio da imanência, a eliminação do temor diante de um mundo que se tornou estranho com a expulsão do estado de imanência paradisíaca.

Mundo, cuja inconstância provocou aquele sentimento de desconfiança e temor, e que se tornou o dilema do Cristianismo. Santo Agostinho (1996, p. 386) referindo-se ao caráter passageiro das coisas corruptíveis, diz que "Essa felicidade brilhante como o vidro e como ele frágil, vive-se no terrível receio de que de repente se estilhace". Trata-se, evidentemente, do temor de que qualquer felicidade mundana se corrompa, de que o mundo não se mostre capaz de nos receber plenamente. Daí o recurso, forjado a partir do impulso do medo, a uma superestrutura que fundamente outra felicidade mais duradoura e inabalável, de uma dimensão 
eterna da existência, por meio da qual se torne possível uma reconciliação definitiva, um termo absoluto, uma felicidade de aço inoxidável.

Essa reunificação final é aquela que cancelará o caráter fragmentário e corrutível da vida temporal com seu falso e enganador brilho de vidro. Ela eliminará a sensação de insegurança e medo por meio da postulação de uma vida eterna. Afinal, trata-se de responder à altura à sensação permanente de que "não é difícil aos malignos demônios enganarem-nos" (AGOSTINHO, 1996, p. 422). Observe que somente uma tal sensação de fragilidade absoluta exige, como solução, uma vida absolutamente segura. Somente uma profunda insegurança e desconfiança com relação ao que nos cerca, demanda um apoio absoluto, um final definitivo. Aquilo que repousa no fundo da alma cristã é, portanto, a falta de fé, o temor e a insegurança com relação a esse mundo da felicidade de vidro.

Essa reunificação final é, em termos cristãos, a reconstituição do corpo místico de Cristo, tornada possível justamente pela sua crucificação e pela constituição da Igreja renascida daí. Sua formulação cristã, elaborada por São Paulo, exprime adequadamente o que o espírito poderia ter postulado para si mesmo como meta na "Enciclopédia": "Porque, assim como o corpo é um, e tem muitos membros, e todos os membros do corpo, embora muitos, formam um só corpo, assim também é Cristo" (1 Corintos 12:12).

Essa crucificação da transcendência implica em uma restituição da totalidade sob a forma do domínio próprio, da realização da autonomia absoluta. Isto é, trata-se de que o espírito seja capaz de reconstituir-se através do processo dialético de suprassunção do que lhe é estranho, refazendo plenamente a imanência da qual os velhos europeus se julgaram expulsos pelo pecado de Adão. O que o espírito busca é consolidar uma unidade construída pelo esforço do conceito, a despeito de qualquer fratura e alienação que possam intervir como obstáculos. Ele procura sustentar-se integralmente, dar-se uma vida totalmente articulada e dotada de sentido, fazer-se como se é, tornar-se consciente de si e devir, por meio dessa consciência, inteiramente transparente para si mesmo. Essa totalidade exige uma unificação e uma reconciliação do outro como si mesmo, operada pela energia original do sentimento da falta e insegurança. Sentimento de ter sido excluído do Paraíso e de, fora dele, não poder mais encontrar-se consigo mesmo.

A matriz problemática a que a "Enciclopédia" tenta fazer frente é a sensação originária de exílio e, a partir dela, do temor diante da fratura e da alienação que forja para si a figura renovada e potente de forças estranhas e ameaçadoras - demônios, muitos demônios e depois outros tantos demônios. Daí uma desconfiança generalizada com tudo que constitui a vida e também a necessidade crescente de segurança, características do ocidente cristão. 
A solução proposta pela "Enciclopédia" afirma que não há nenhuma ameaça autêntica porque, afinal de contas, trata-se sempre do espírito lutando contra si mesmo e não de uma batalha contra o definitivamente outro, o ontologicamente monstruoso, o mal como tal. Então parece haver um sentido civilizatório de alívio na efetivação do projeto hegeliano. Sua realização demonstraria que não há o que temer após a crucificação dos fragmentos da vida positiva: tudo se torna o espírito tentando chegar a si mesmo, tudo se opera em um palco unificado que narra uma mesma história sem opositores verdadeiros. Mesmo o sofrimento que pode surgir nesse enredo não pode ser debitado da conta da autenticidade do espírito porque se trata, em último caso, das dores do parto, da emersão difícil de dentro da ignorância e da alienação.

O que a "Enciclopédia" propõe como desenlace é que as partes tenham sido reconciliadas e uma nova unidade tenha refeito os fragmentos da vida. Ou seja, trata-se de que essa imanência recém-adquirida permita uma renovada entrada no Paraíso. Tudo o que se perdeu antes foi restituído em uma ordem autoproduzida. Todas as ameaças e todos os demônios sutis foram finalmente cancelados, porque mostraram-se como o próprio espírito perdido para si mesmo. O que um dia foi um Paraíso dado, agora é o Paraíso refeito pelo esforço conceitual do espírito. E esse não pode mais ser perdido, ao contrário do primeiro, obtido pela graça original traída.

\section{A "Enciclopédia" vista do Brasil}

O fato histórico relevante aqui é que a sensação de se viver em um Paraíso que não pode ser perdido, porque se trata de algo instituído interiormente pelo espírito, jamais se tornou efetiva como experiência humana. O que parece ter perdurado, além da "Enciclopédia" e sobre ela, foi a sensação de exílio e temor, justamente aquela que deveria ter sido extinta pelo advento do saber enciclopédico. A velha Europa não só não é um mundo pacificado, como não parece ter condições de instituir algo semelhante dentro dos parâmetros atuais em que vive. Isso, por si só e dentro dos seus próprios parâmetros, leva a crer que há algo de errado com a solução proposta pela "Enciclopédia".

Embora me pareça impossível ser claro aqui a esse respeito, observo que avalio de uma perspectiva que não é nem ocidental, nem cristã, nem histórica. Isto é, falo daquela perspectiva que é própria do Brasil (SILVEIRA, 2015): o nosso ponto de vista.

Do lado de cá do Atlântico, o projeto hegeliano da "Enciclopédia" parece responder àquele sentimento cristão europeu de extrema desconfiança e insegurança com relação ao caráter transitório da vida e à inconstância da felicidade. O predomínio existencial desse sentimento parece ter conduzido a uma prática filosófica específica, antes e depois de Hegel. Com efeito, a filosofia hegeliana ocupou-se com a restituição da 
autonomia absoluta que substituiria o desconforto do domínio externo pelo autocontrole ou pela unificação de si pelo esforço do conceito.

Nessa mesma direção, não parece estranho que o ser humano tenha sido definido, já em pleno Século XX, como um ser que se angustia diante da morte. Mais do que isso: que "manter-se nessa ameaça" (HEIDEGGER, 1986, p. 343) diante da morte tenha se tornado uma espécie de virtude digna de ser promovida pela filosofia. Tudo indica que o medo tornou-se a experiência cultural mais importante da velha Europa cristã. O problema de uma vida cheia de temor e ameaça parece ter se sobreposto à própria solução hegeliana. Na verdade, a perseveração do medo e sua conversão em virtude parecem dizer que a velha Europa se viciou dessa sensação. De qualquer modo, se a morte ainda perturba tanto aos europeus é porque o paraíso refeito na "Enciclopédia" não se tornou mesmo como uma solução culturalmente efetiva.

Não sendo cristãos, nem sentindo na pele a experiência crucial da fragilidade da felicidade, também não solicitamos uma felicidade de aço. Isto é, a solucionática da "Enciclopédia" nos é totalmente estranha. Com efeito, ela não atinge nada de substantivo na vida brasileira, de tal forma que aqui ela só pode ser interpretada como uma solução de problemas culturais alienígenas. É claro que, na medida em que alguns de nós - mas não do nosso próprio ponto de vista brasileiro - ainda tentam imitar a velha Europa, a "Enciclopédia" pode ser uma obra relevante.

Seja como for, o fato que considero necessário destacar é que levar a "Enciclopédia" a sério do ponto de vista brasileiro, implicaria contraditoriamente em abrir mão do postulado hegeliano de que a filosofia é uma atividade que tenta apreender o mundo atual que nos cerca, de que ela é a elevação de nossa época ao pensamento ou, ainda, reconhecer a "rosa na cruz do sofrimento presente", em hegelianês (HEGEL, 1997, p. XXXVIII). Isso porque colocar esse princípio hegeliano em prática significa pensar o Brasil pelos seus próprios termos e não pensar o Brasil pelos olhos do hegelianismo da "Enciclopédia". Se há algo interessante aqui é o fato de que a "Enciclopédia" é uma obra filosófica que se anula, justamente quando entra em um mundo que não é europeu cristão, ocidental nem histórico.

Ressalto que a "Enciclopédia" se anula pela sua disposição de pretender ser a apreensão filosófica do que ocorre no presente. Sendo assim, as opções abertas diante de um brasileiro hegeliano parecem simples: pensar o passado da velha Europa retratado na "Enciclopédia" ou pensar o Brasil de hoje pelos seus próprios termos. Se a filosofia é pensar o presente, então a "Enciclopédia" não é filosofia porque é uma solução da velha Europa e se ela é filosofia, então seguramente a filosofia não consiste em pensar o presente - mas o passado de que ela trata.

O que se pode ver pelos olhos do Brasil é que a "Enciclopédia" é uma obra produzida pela velha Europa cristã, tentando resgatar o homem de sua pretensa queda da imanência. Mas esse é um problema que nunca nos 
afetou essencialmente. Sabemos, pelo menos desde Manoel da Nóbrega (2006) passando por Flusser (2014), que o Cristianismo entre nós nunca foi praticado da maneira cristã. Para não me alongar muito nessa tese já conhecida, cito a sintética afirmação de Oliveira Lima de que essa religião entre nós "vive [...] como num pouco d'água as gotas de vinho indispensáveis para colorir-lhes o aspecto ou alterar-lhe o aroma" (2000, p. 128). O Cristianismo apenas recobriu a superfície da vida brasileira, dandolhe certo aroma e cor, mas sem alterá-la.

Não sendo nosso o problema, não poderia se mostrar adequada para nós a solução contida na "Enciclopédia" hegeliana. O que se pode dizer de uma solução para problemas alienígenas? Certamente que ela pode ser excelente para eles, mas não nos serve e nem nos é pertinente, assim como o problema que lhe deu origem. Embora me pareça que ela também não atingiu o objetivo europeu de promover um mundo restituído e sem cisões, o que é relevante aqui é que ela nada nos diz sobre a vida brasileira.

Não há, obviamente, nenhum problema em se ler a "Enciclopédia" para conhecer os problemas e soluções dos velhos europeus. Para isso se requer preferencialmente a adoção do ponto deles. Mas isso apenas nos torna ilustrados ou eruditos em filosofia europeia. Isso nada nos diz de pertinente com relação a nosso próprio modo de vida. A "Enciclopédia" nada nos diz sobre nossas rosas - que, aliás, não se encontram inseridas em cruzes, como defendem a estética e a ética cristãs da beleza e do valor mórbido do sofrimento.

Então, parece-me que posso dizer que a "Enciclopédia" hegeliana, de nosso ponto de vista, é uma tentativa de solução para alguns daqueles problemas dos velhos cristãos europeus. Ela só adquire relevância filosófica quando vista do velho continente. Daqui, do novo mundo, ela ilustra um profundo pessimismo com relação ao homem e ao mundo. Pessimismo que nunca experimentamos. Daqui, de onde renovamos anualmente nossa felicidade carnavalesca, vivemos a crença de que é bom sermos muitos. 


\section{Referências bibliografia}

COIMBRA, C. Fenomenologia da cultura brasileira. São Paulo: Lisa, 1971.

FANON, F. Peau noire masques blancs. Paris: Éditions du Seuil, 1952.

FAORO, R. $O$ debate político no processo da independência. Rio de janeiro: Conselho Federal de Cultura, 1973.

FLUSSER, V. Fenomenologia do brasileiro. s. d. Disponível em http://www.iphi.org.br/sites/filosofia_brasil/Vilem_Flusser_-

_Fenomenologia_do_brasileiro.pdf Consultado em 17/02/2014.

HEGEL, G. Lecciones sobre filosofía de la religión 2. Trad. R. Ferrara. Madrid: Alianza, 1985.

- Encyclopédie des sciences philosophiques. I - La science de la logique. Trad. B. Bourgeois. Paris: J. Vrin, 1986.

. Encyclopédie des sciences philosophiques. III - Philosophie de

l'esprit. Trad. B. Bourgeois. Paris: J. Vrin, 1988. 1992. 2v.

Fenomenologia do espírito. Trad. Paulo Menezes. Petropólis: Vozes, Princípios da filosofia do direito. Trad. O. Vitorino. São Paulo: Martins Fontes, 1997.

Encyclopédie des sciences philosophiques. II - Philosophie de la nature. Trad. B. Bourgeois. Paris: J. Vrin, 2004.

HEIDEGGER, M. Ser e tempo. Trad. M. Schuback. Petrópolis/Bragança Paulista: Vozes/Editora Universitária São Francisco, 1986.

KANT, I. Fundamentação da metafísica dos costumes. São Paulo: Abril Cultural, 1973.

LABARRIÈRE, P.-J. La sursomption du temps et le vrai sens de l'histoire conçue. Revue de Métaphysique ET de Morale, n. 1, jan.-mar, pp. 92-100, 1979.

NÓBREGA, M. da. Diálogo sobre a conversão do gentio. São Paulo: Metalibri, 2006.

OLIVEIRA LIMA. Formação histórica da nacionalidade brasileira. Rio de Janeiro/São Paulo: Topbooks/Publifolha, 2000.

ROCHA, G. Der Leone have sept cabezas. Produzido por Mapa Filmes, Polifilm e C. Antoine, 1970.

SANTO AGOSTINHO. A cidade de Deus. Trad. J. Dias Pereira. Lisboa: Calouste Gulbenkian, 1996.

SILVEIRA, R. A presentação do Brasil. Santa Cruz Cabrália: Ronie Alexsandro Teles da Silveira, 2015. Disponível para download em http://roniefilosofia.wix.com/ronie\#!livros/c1qo4 